Impact of COVID-19 on smell and taste

\title{
1 Self-reported taste and smell disorders in patients with COVID-19: distinct
}

\section{features in China}

Jia Song, M.D., Ph.D..$^{*}$, Yi-ke Deng, M.D., Ph.D..$^{*}$, Hai Wang, M.D., Ph.D. ${ }^{1 *}$, Zhi-Chao Wang, M.D., Ph.D. ${ }^{1}$, Bo Liao, M.D., Ph.D. ${ }^{1}$, Jin Ma, M.D., Ph.D. ${ }^{1}$, Chao He, M.D., Ph.D. ${ }^{1}$, Li Pan, M.D., Ph.D. ${ }^{1}$, Yang Liu, M.D., Ph.D. ${ }^{1}$, Isam Alobid, M.D., Ph.D. ${ }^{2}$, De-Yun Wang, M.D., Ph.D. ${ }^{3}$, Ming Zeng, M.D., Ph.D. ${ }^{1 \dagger}$, Joaquim Mullol, M.D., Ph.D..$^{2 \dagger}$, Zheng Liu, M.D., Ph.D. ${ }^{1 \dagger}$

${ }^{1}$ Department of Otolaryngology-Head and Neck Surgery, Tongji Hospital, Tongji Medical College, Huazhong University of Science and

7 Technology, Wuhan, P.R. China

${ }^{2}$ Rhinology Unit and Smell Clinic, ENT Department, Hospital Clinic, IDIBAPS, Universitat de Barcelona, CIBERES, Barcelona, Catalonia, Spain

${ }^{3}$ Department of Otolaryngology, Yong Loo Lin School of Medicine, National University of Singapore, Singapore

Abstract

Objectives: We aimed to explore the frequencies of nasal symptoms in patients with COVID-19, including loss of smell and taste, as well as their presentation as the first symptom of the disease and their association with the severity of COVID-19.

Methods: In this retrospective study, 1,206 laboratory-confirmed COVID-19 patients were included and followed-up by telephone call one month after discharged from Tongji Hospital, Wuhan. Demographic data, laboratory values, comorbidities, symptoms, and numerical rating scale scores (0-10) of nasal symptoms were extracted from the hospital medical records, and confirmed or reevaluated by the telephone follow-up.

Results: From COVID-19 patients ( $\mathrm{N}=1,172)$ completing follow-up, $199(17 \%)$ subjects had severe COVID-19 and 342 (29.2\%) reported nasal symptoms. The most common nasal symptom was loss of taste $(20.6 \%$, median score $=6)$, while $11.4 \%$ had loss of smell $($ median score $=5)$. The incidence of nasal symptom including loss of smell and loss of taste as the first onset symptom was $<1 \%$ in COVID-19 patients. Loss of smell or taste scores showed no correlation with the scores of other nasal symptoms. Loss of taste scores, but not loss of smell scores, were significantly increased in severe vs. non-severe COVID-19 patients. Interleukin (IL)-6 and lactose dehydrogenase (LDH) serum levels positively correlated with loss of taste scores. About $80 \%$ of COVID-19 patients recovered from smell and taste dysfunction in 2 weeks. 
medRxiv preprint doi: https://doi.org/10.1101/2020.06.12.20128298; this version posted June 15, 2020. The copyright holder for this preprint (which was not certified by peer review) is the author/funder, who has granted medRxiv a license to display the preprint in perpetuity. All rights reserved. No reuse allowed without permission.

Impact of COVID-19 on smell and taste

25 Key words: Loss of taste; loss of smell; upper respiratory tract; coronavirus disease 2019; severe

26 acute respiratory syndrome coronavirus 2

27

28

29

30

31

32

33

34

35

36

37

38

39

40

41

42

43 
medRxiv preprint doi: https://doi.org/10.1101/2020.06.12.20128298; this version posted June 15, 2020. The copyright holder for this preprint (which was not certified by peer review) is the author/funder, who has granted medRxiv a license to display the preprint in perpetuity.

All rights reserved. No reuse allowed without permission.

Impact of COVID-19 on smell and taste

\section{Introduction}

Last December 2019, a cluster of viral pneumonia cases identified as coronavirus disease 2019 (COVID-19), was reported in Wuhan, China. Subsequently, severe acute respiratory syndrome coronavirus 2 (SARS-CoV-2) has been identified to be the pathogenic cause of COVID-19 [1-3]. This newly recognized illness has spread rapidly throughout Wuhan (Hubei province) to allover the world [4-6]. The diagnosis of the COVID-19 is based on clinical manifestations, contact history report, chest computed tomography (CT) and positive result of nucleic acid test [7-9]. Due to the uncertainty of contact history and the rush to hospitals that could run out of the essential equipment for test during the world-wide pandemic, efforts to identify additional diagnostic or prognostic symptoms of COVID-19 has significant value in mitigating transmission.

The clinical spectrum of COVID-19 ranges from asymptomatic to severe ill cases $[1,2,6,7$, 10-12]. The most common symptom of COVID-19 is fever, and other common systemic symptoms include dyspnea, cough, nausea and vomiting, etc $[6,7,10]$. In addition, olfactory and taste disorder have been recently noted in patients with COVID-19. An early study conducted in Italy reported $33.9 \%$ of hospitalized COVID-19 patients shown at least one taste or olfactory disorders [13]. Later studies in Europe reported that about 75\%-85\% COVID-19 patients had olfactory dysfunction and about 70\%-88\% patients had gustatory dysfunctions [14]. Very recently, similar prevalence of smell and taste disorder has been found in COVID-19 patients in USA [15]. It is indicated that smell or taste change may be a strong predictor for a COVID-19 positive test result and may serve as an early alerting symptom for COVID-19 [16]. However, an early study based on analyzing electronic medical records of 214 patients with COVID-19 in Wuhan, China reported that the ratio of patients complaining of loss of taste and loss of smell was only $5.6 \%$ and $5.1 \%$, respectively [17], significantly lower than those reported in Europe and USA. One potential reason 
medRxiv preprint doi: https://doi.org/10.1101/2020.06.12.20128298; this version posted June 15, 2020. The copyright holder for this preprint (which was not certified by peer review) is the author/funder, who has granted medRxiv a license to display the preprint in perpetuity.

All rights reserved. No reuse allowed without permission.

Impact of COVID-19 on smell and taste

67 for the low ratios in China may be related to incomplete medical records of COVID-19 patients under actual emergency situation, which underestimated the incidences of upper airway tract manifestations. Nevertheless, it is also possible that there are different responses to SARS-CoV-

702 infection in people with distinct ethnic/culture background. Therefore, more accurate evaluation

71 of upper airway tract manifestations in COVID-19 patients should be conducted to figure out the

72 clinical importance of smell and taste dysfunction in the early diagnosis of COVID-19 for Chinese

73 and to elucidate whether there are different clinical manifestations between patients with distinct

74 ethnic/culture background. Moreover, several important questions remain to be answered. How

75 severe are the upper airway tract symptoms in patients with COVID-19? Is there any correlation

76 between olfactory and taste disorders and other nasal symptoms such as nasal obstruction? Will

77 the severity of olfactory or taste disorder be associated with the severity of COVID-19? Will there

78 be a full recovery of olfactory or taste disorder and how long it will take?

In this retrospective study, we investigated the COVID-19 patients discharged from Tongji medical record analysis and reevaluation of upper airway symptoms by the telephone follow-up,

82 we aimed to explore the frequencies of nasal symptoms in patients with COVID-19, including loss

83 of smell and taste, as well as their presentation as the first symptom of the disease and their association with the severity of COVID-19.

\section{Methods}

\section{Study participants}


medRxiv preprint doi: https://doi.org/10.1101/2020.06.12.20128298; this version posted June 15, 2020. The copyright holder for this preprint (which was not certified by peer review) is the author/funder, who has granted medRxiv a license to display the preprint in perpetuity.

All rights reserved. No reuse allowed without permission.

Impact of COVID-19 on smell and taste

A single center, retrospective cohort study was conducted in Wuhan, China, where COVID-

19 initially outbroke. We obtained the electronic medical records for discharged COVID-19

patients between January 27, 2020 and March 10, 2020, who initially admitted to the Tongji

Hospital. The diagnosis was made on the basis of guidance for diagnosis and management of

\section{Clinical characteristic, laboratory assessment, and telephone follow-up}

The degree of severity of COVID-19 was defined as severe and non-severe at the time of admission using the American Thoracic Society guidelines for community-acquired pneumonia commodities related to COVID-19 were extracted from electronic medical records. In addition, the results of laboratory assessments on admission were also collected from electronic medical records. All laboratory testing was performed according to the clinical care needs of the patients. Laboratory assessments consisted of a complete blood routine, blood biochemistry, coagulation function, infection biomarkers and immune function. All data were entered into a computerized

107 database and cross-checked. 
medRxiv preprint doi: https://doi.org/10.1101/2020.06.12.20128298; this version posted June 15, 2020. The copyright holder for this preprint (which was not certified by peer review) is the author/funder, who has granted medRxiv a license to display the preprint in perpetuity.

All rights reserved. No reuse allowed without permission.

Impact of COVID-19 on smell and taste

110 records and were confirmed and reevaluated by the telephone follow-up. The severity of upper

111 respiratory tract symptoms was scored by patients on a numerical rating scale of 0 - 10 , with 0 being

112 "no complaint whatsoever" and 10 being "the worst imaginable complaint" [19, 20]. Six major

113 symptoms of upper respiratory tract were focused on: nasal obstruction, rhinorrhea, nasal itching,

114 sneezing, loss of smell, and loss of taste. The severity of loss of smell and loss of taste was defined

115 as follows: Mild $=$ score 0-3; Moderate $=$ score 4-7; Severe $=$ score 8-10 [19, 20]. The difference

116 between the symptom of loss of smell and loss of taste was explained to the patients very carefully

117 during telephone follow-up according to previous studies [21, 22]. The detailed questionnaire 118 showed in this article's Online Supplement.

\section{Statistical Analysis}

For continuous variables, Mann-Whitney $U$ 2-tailed test was used for between-group

122 comparison. Chi-square test was applied to compare the difference in proportions between groups.

123 Spearman test was used for correlation analysis. Difference was considered to be statistically

124 significant if a $P$ value was less than 0.05 . These statistical analyses were performed by using an

125 IBM SPSS 22.0 package (SPSS Inc, Chicago, IL).

127 Results

128 Demographic and clinical characteristics

Totally 1,206 patients were enrolled and 1,172 of them completed questionnaires. The followup rate was $97.2 \%$. Reasons of the lost cases included: refusal to answer questions for personal 
medRxiv preprint doi: https://doi.org/10.1101/2020.06.12.20128298; this version posted June 15, 2020. The copyright holder for this preprint (which was not certified by peer review) is the author/funder, who has granted medRxiv a license to display the preprint in perpetuity.

All rights reserved. No reuse allowed without permission.

Impact of COVID-19 on smell and taste

131 reasons $(n=23)$; unable to provide accurate information $(n=6)$; phone calls were not answered

$132(\mathrm{n}=5)$. The demographic and clinical characteristics of 1,172 patients are shown in Table 1. The median age was 61 years (IQR, 48-68), and 577 (49.2\%) were men. The ratio of severe cases was $17 \%(199 / 1172)$.

Of the 1172 cases, $399(25.1 \%)$ reported with at least one comorbidity, and $17.3 \%$ having one or more respiratory comorbidities, including allergic rhinitis (AR, 9.8\%), chronic rhinosinusitis (CRS, 6.1\%), asthma (2.5\%) and chronic obstructive pulmonary disease (COPD, 0.9\%). The frequency of patients with at least one nasal symptom was up to $29.2 \%$, including nasal obstruction (8.6\%; median score, 3$)$, rhinorrhea (10.3\%; median score, 3$)$, nasal itching (4.9\%; median score, 2), sneezing (11.0\%; median score, 2), loss of smell (11.4\%; median score, 5), and loss of taste 141 (20.6\%; median score, 6). The incidence of symptom reported as the first onset symptom was $<$ $1421 \%$ for each individual nasal symptom, including loss of smell and taste. No difference in 143 frequency of patients with loss of smell or taste disorder was found between severe and non-severe 144 COVID-19 cases (Fig 1, A). The scores of loss of taste but not smell were significantly higher in 145 the patients with severe vs. non-severe COVID-19 (7 [5- 9] vs. 6 [4- 8]; $P=0.03$ ) (Fig 1, B). No difference in frequency or score for the other nasal symptoms was found between severe and non147 severe disease. The data is shown in Table 1 and Fig 1.

149 tract, which could be impacted by the nasal dysfunction [22]. Hence, we analyzed the relations between the scores of loss of taste and smell and other nasal symptoms. We failed to find any 151 correlation between loss of taste or loss of smell scores and scores of the other nasal symptoms 152 (Fig E1 in the Online Supplement). However, loss of taste showed mild positive correlation with 153 loss of sense of smell $(\rho=0.25, P<0.01)$ (Fig E1 in the Online Supplement). 
medRxiv preprint doi: https://doi.org/10.1101/2020.06.12.20128298; this version posted June 15, 2020. The copyright holder for this preprint (which was not certified by peer review) is the author/funder, who has granted medRxiv a license to display the preprint in perpetuity.

All rights reserved. No reuse allowed without permission.

Impact of COVID-19 on smell and taste

Given the possibility that some patients might not well distinguish the taste and smell disorder

$155[21,22]$, we compared the differences among the patients only with one smell or taste disorder,

156 the patients with both smell and taste disorder, and the patients without any of these two symptoms.

157 We found that the patients without loss of smell and taste were significant elder than the patients

158 in the other two groups (62 [48-69] years vs 59 [46-67] years, 57.5 [42.75-66] years, $P=0.03)$.

159 No other difference of clinical characteristics and laboratory measurements was found among the 160 patients in three groups. The data is shown in Table E1 in the Online Supplement.

\section{The recovery of olfactory and taste function}

We found that $82.1 \%(110 / 134)$ of patients with loss of sense of smell and $95.5 \%(231 / 242)$

164 of patients with loss of taste recovered in one month after discharge. The symptomatic duration 165 days showed no difference between the patients with loss of smell and taste (8 [6-13.25] vs 7 [514] days, $P=0.52$ ) (Fig 1, C). Most of them recovered in 14 days after onset of symptom (Fig 1, COVID-19 and 95.5\% patients with non-severe COVID-19 recovered, and no difference showed neither $(P=0.99)$ (Table 1$)$. The data is also shown in Table 1. Due to the limited number of

171 patients with unrecovered symptoms, we did not compare the differences between recovered and 172 unrecovered patients with loss of smell or loss of taste. 
medRxiv preprint doi: https://doi.org/10.1101/2020.06.12.20128298; this version posted June 15, 2020. The copyright holder for this preprint (which was not certified by peer review) is the author/funder, who has granted medRxiv a license to display the preprint in perpetuity.

All rights reserved. No reuse allowed without permission.

Impact of COVID-19 on smell and taste

174

175

176

177

178

179

180

181

182

183

184

185

186

187

188

189

190

191

\section{Clinical characteristics of COVID-19 patients with different severity of taste and smell} disorder

Since the taste disorder was the most common upper respiratory tract symptoms and showed positive correlation to the symptom of loss of smell, we subsequently compared the differences among the COVID-19 patients with different severity of loss of taste (Table 2) and loss of smell (Table 3). First, we divided 242 COVID-19 cases with loss of taste into mild (score, 1-3; 19.0\%), moderate (score, $4-7 ; 48.8 \%$ ) and severe (score, $8-10 ; 32.2 \%$ ) group by symptom scores, similar to the visual analogue scale system of nasal symptoms [19, 20]. More COVID-19 cases with severe illness were found in the severe loss of taste group than in the moderate loss of taste group (26.9\% vs $12.7 \%, P=0.03)$. The symptom duration of loss of taste was significantly longer in moderate and severe taste dysfunction group as compared to the mild taste dysfunction group (8 days [613.25], 10 days [5-15] vs 5 days [3.5-8], $P<0.01$ ) (Fig 2). In addition, serum levels of interleukin6 (IL-6) and lactate dehydrogenase (LDH) were significantly increased in patients with severe compared to mild and moderate loss of taste group (Table 2). Levels of IL-8 were significantly increased in severe and moderate compared to mild loss of taste group (Table 2). The characteristics of the patients with different severity of taste disorder are shown in Table 2. In addition, IL-6 and LDH showed mild positive correlations to the symptom scores of loss of taste $(\rho=0.15, P=0.03 ; \rho=0.21, P<0.01$, respectively; Fig 3).

As to the comparison among different severity of loss of smell, we divided the 134 patients with loss of sense of smell into mild (score, 1-3, 23.9\%), moderate (score, 4-7; 35.8\%) and severe (score, 8-10; 40.3\%) group. No prominent difference in clinical and laboratory measurements was found among the patients with different severity (Table 3 and Fig 2). 
medRxiv preprint doi: https://doi.org/10.1101/2020.06.12.20128298; this version posted June 15, 2020. The copyright holder for this preprint (which was not certified by peer review) is the author/funder, who has granted medRxiv a license to display the preprint in perpetuity.

All rights reserved. No reuse allowed without permission.

Impact of COVID-19 on smell and taste

\section{Discussion}

To the best of our knowledge, this is the first study on detailed information of manifestations of the upper respiratory tract of the hospitalized patients with COVID-19 in China. We reported the manifestations of upper respiratory tract in a cohort of 1,172 patients with laboratoryconfirmed COVID-19 in Wuhan, China. Overall, 17\% subjects were categorized as severe COVID-19, this percentage being similar with previous reports from China $[7,10]$. Most of the common systemic signs and symptoms of disease such as fever, fatigue, and anorexia, etc. reported in previous studies were also observed in our cohort $[2,7,10]$. Nevertheless, under urgent admission of COVID-19 patients, compared to systemic symptoms and comorbidities, nasal symptoms and upper airway comorbidities were very likely incompletely documented and underestimated in previous studies based on medical record analysis [7, 23]. In order to overcome this limitation in real-world setting, we did recalled questionnaires by phone call to reevaluate the presence of airway comorbidities, and frequency and severity of nasal symptoms. As a result, the frequencies of COVID-19 patients with AR and CRS were 9.8\% and 6.1\%, respectively. Previous studies have reported that adult AR and CRS in general population in China were $17.6 \%$ and $8 \%$, respectively, these being higher than the reported for COVID-19 [24, 25]. Recent studies indicate that the increasing eosinophils may be an indicator of COVID-19 improvement [26, 27]. Hence, we cannot rule out the possibility that the comorbidities of allergic and eosinophilic diseases such as AR might be potential protective factors for severe COVID-19.

Here, we found that upper respiratory tract symptoms were identified in $29.2 \%$ patients with COVID-19, with nasal obstruction, rhinorrhea, nasal itching and sneezing presenting in mild/moderate severity and loss of smell and taste presenting in moderate/severe severity. All of these upper respiratory tract symptoms have been commonly reported in other respiratory viral 
medRxiv preprint doi: https://doi.org/10.1101/2020.06.12.20128298; this version posted June 15, 2020. The copyright holder for this preprint (which was not certified by peer review) is the author/funder, who has granted medRxiv a license to display the preprint in perpetuity.

All rights reserved. No reuse allowed without permission.

Impact of COVID-19 on smell and taste

219 infection, such as influenza and rhinovirus [28-30]. Our data suggest that similar with the common

220 respiratory virtues, SARS-CoV-2 may be able to infect upper respiratory tract mucosa and cause

221 similar symptoms $[22,29,31]$. In addition, the result in our Wuhan cohort revealed that the self-

222 reported symptoms of upper respiratory tract were not the first symptom in most COVID-19

223 patients, doubting the diagnostic value of these symptoms preceding the onset of full-blown

224 clinical disease. However, our study only included hospitalized COVID-19 patients while the

225 clinical manifestations of COVID-19 can range from asymptomatic infection to severe pneumonia

$226[2,7,32]$. Further investigations on non-hospitalized infected patients and patients with likely

227 sudden onset anosmia will help to determine the role of upper airway symptoms, particular loss of

228 smell and taste, as a screening tool for COVID-19.

229

Interestingly, the loss of taste and smell were the most common upper respiratory tract

symptoms observed in COVID-19 patients in Wuhan, with $17.5 \%$ patients having only smell or

taste disorder and 7.3\% patients having both symptoms. By integrating medical record analysis

and follow-up confirmation and reevaluation after discharge, we reported higher rates of smell and

taste disorder in the hospitalized patients than an early report from Wuhan, which relied on medical

disorder in our cohort were much lower than those reported in Europe and America [13-16, 33]. It

may be related to the different characteristics of COVID-19 patients. In our study, asymptomatic

patients and non-hospitalized patients with mild symptoms were not included. It is also likely that

240 disease caused by either SARS-CoV-1 or middle east respiratory syndrome coronavirus, that 
medRxiv preprint doi: https://doi.org/10.1101/2020.06.12.20128298; this version posted June 15, 2020. The copyright holder for this preprint (which was not certified by peer review) is the author/funder, who has granted medRxiv a license to display the preprint in perpetuity.

All rights reserved. No reuse allowed without permission.

Impact of COVID-19 on smell and taste

242 disorder in a patient infected with SARS- CoV-1 [34]. Nevertheless, olfactory and taste disorders

243 are well known to be widely associated with a number of viral infections $[35,36]$. The frequency

244 of patients with loss of smell in the present study was similar to that of post-viral olfactory

245 dysfunction (PVOD) caused by the common respiratory virus, such as influenza with a ratio of

246 about $17 \%[29,31]$. PVOD can be caused by mechanical obstruction of odorant transmission due

247 to edema of nasal mucosa, and/or the inflammatory impairment of the olfactory neuroepithelium

248 and even central nervous systems [22, 31, 37, 38]. We found that the scores of taste and smell

249 dysfunction showed no correlation with the scores of the other nasal symptoms including nasal

250 obstruction, disfavoring a role of mechanical obstruction in the dysfunction of smell and taste. In

251 fact, the symptom scores indicate that COVID-19 patients suffer from mild/moderate nasal

252 obstruction and rhinorrhea, despite moderate/severe olfactory and taste disorder. SARS-CoV-1 has

253 demonstrated a transneural penetration through the olfactory bulb in mice model [39]. Angiotensin

254 converting enzyme 2, which is used by SARS-CoV-1 and SARS-CoV-2 to invade the host cells,

255 is widely expressed on the epithelial cells in nasal and oral cavity [40,41]. These evidence suggest

256 a neurological involvement in smell and taste disorder caused by SARS- CoV-2 infection. In this

257 study, COVID-19 patients with severe illness had more severe taste disorder. In addition, serum

258 levels of IL-6, a pro-inflammatory cytokine, were elevated in patients with severe taste disorder,

259 and positively correlated with the loss of taste scores. Previous studies demonstrated that the pro-

260 inflammatory cytokines were able to impair the function of taste buds directly, thus leading to taste

261 dysfunction [42, 43].

The present study revealed that $95.5 \%$ patients with loss of taste and $82.1 \%$ patients with loss

263 of smell recovered spontaneously, and most of them in 2-week time, although the severe

264 impairment of olfactory and smell function may lead to delayed recovery. The spontaneous 
medRxiv preprint doi: https://doi.org/10.1101/2020.06.12.20128298; this version posted June 15, 2020. The copyright holder for this preprint (which was not certified by peer review) is the author/funder, who has granted medRxiv a license to display the preprint in perpetuity.

All rights reserved. No reuse allowed without permission.

Impact of COVID-19 on smell and taste

265

266

267

268

269

270

271

272

273

274

275

276

277

278

279

280

281

282

283

284

285

286

recovery may be a result of regeneration of the damaged olfactory epithelium and taste buds [44].

Previously, oral and topical corticosteroids have been proposed to treat viral-associated olfactory loss. However, systemic corticosteroids may impair the viral clearance. Given to the high rate of spontaneous recovery of olfactory and taste function, it seems that there is no need to use corticosteroids for treating olfactory and smell disorder in patients with COVID-19, although their administration can be continued to treat comorbidities such as AR and CRS [45].

We have to acknowledge that there are several limitations of this study. First, the self-reported and recalled symptoms and comorbidities without diagnostic testing, especially for the symptomatic information of loss of smell and taste obtained over a month after onset, might contribute to under- or over- estimation of the prevalence of these symptoms, and the strength of association with the clinical outcomes. Second, the self-report and questionnaire-based evaluation could not clearly discriminate the symptoms of loss of smell and taste in patients with COVID-19. It is the inherent limitation of the study based on self-reported data. Three, it was impossible to include the fatal cases due to the incomplete medical records regarding upper airway symptoms and comorbidities, and impossible telephone recall. Fourth, asymptomatic patients and nonhospitalized patients with mild symptoms were missed in this study. Fifth, we cannot preclude the influence of AR and CRS comorbidity on the presentation of upper airway symptoms during COVID-19. However, most of our patients claimed that their primary AR or CRS were under control at baseline and we found no difference in upper airway symptoms between patients with and without AR or CRS comorbidity (data not shown).

\section{Conclusion}


medRxiv preprint doi: https://doi.org/10.1101/2020.06.12.20128298; this version posted June 15, 2020. The copyright holder for this preprint (which was not certified by peer review) is the author/funder, who has granted medRxiv a license to display the preprint in perpetuity.

All rights reserved. No reuse allowed without permission.

Impact of COVID-19 on smell and taste

288

To the best of our knowledge, this is the largest retrospective cohort study focusing on the

289 symptoms of upper respiratory tract in patients with COVID-19 in China. We found that nearly

290 one third of COVID-19 patients got the upper respiratory tract symptoms. Loss of smell affected

291 one out of ten patients with COVID-19 while loss of taste was the most common upper respiratory

292 infection. Finally, about $80 \%$ of patients spontaneously recovered from olfactory and taste 293 dysfunction in a short term of 2 weeks.

294

295

296

297

298

299

300

301

302

303

304

305

306 
medRxiv preprint doi: https://doi.org/10.1101/2020.06.12.20128298; this version posted June 15, 2020. The copyright holder for this preprint (which was not certified by peer review) is the author/funder, who has granted medRxiv a license to display the preprint in perpetuity.

All rights reserved. No reuse allowed without permission.

Impact of COVID-19 on smell and taste

\section{References}

[1] Zhou P, Yang XL, Wang XG, Hu B, Zhang L, Zhang W, et al. A pneumonia outbreak associated with a new coronavirus of probable bat origin. Nature 2020;579(7798):270-3.

[2] Huang C, Wang Y, Li X, Ren L, Zhao J, Hu Y, et al. Clinical features of patients infected with 2019 novel coronavirus in Wuhan, China. Lancet 2020;395(10223):497-506.

[3] Organization WH. Clinical management of severe acute respiratory infection when novel coronavirus (2019-nCoV) infection is suspected: interim guidance. January 28, 2020 (https://www.who.int/docs/default-source/ coronaviruse/clinical -management-of-novelcov.pdf).

[4] Ghinai I, McPherson TD, Hunter JC, Kirking HL, Christiansen D, Joshi K, et al. First known person-to-person transmission of severe acute respiratory syndrome coronavirus 2 (SARS-CoV-2) in the USA. Lancet 2020;395(10230):1137-44.

[5] Pung R, Chiew CJ, Young BE, Chin S, Chen MI, Clapham HE, et al. Investigation of three clusters of COVID-19 in Singapore: implications for surveillance and response measures. Lancet 2020;395(10229):1039-46.

[6] Yang X, Yu Y, Xu J, Shu H, Xia J, Liu H, et al. Clinical course and outcomes of critically ill patients with SARS-CoV-2 pneumonia in Wuhan, China: a single-centered, retrospective, observational study. Lancet Respir Med 2020.

[7] Guan WJ, Ni ZY, Hu Y, Liang WH, Ou CQ, He JX, et al. Clinical Characteristics of Coronavirus Disease 2019 in China. N Engl J Med 2020.

[8] Zhou F, Yu T, Du R, Fan G, Liu Y, Liu Z, et al. Clinical course and risk factors for mortality of adult inpatients with COVID-19 in Wuhan, China: a retrospective cohort study. Lancet 2020;395(10229):1054-62. 
medRxiv preprint doi: https://doi.org/10.1101/2020.06.12.20128298; this version posted June 15, 2020. The copyright holder for this preprint (which was not certified by peer review) is the author/funder, who has granted medRxiv a license to display the preprint in perpetuity.

All rights reserved. No reuse allowed without permission.

Impact of COVID-19 on smell and taste

[9] The Seventh Revised Trial Version of the Novel Coronavirus Pneumonia Diagnosis and Treatment Ghidance. Available at: http://www.nhc.gov.cn/yzygj/s7652m/202003/a31191442e29474b98bfed5579d5af95.sht $\underline{\mathrm{ml}}$.

[10] Wang D, Hu B, Hu C, Zhu F, Liu X, Zhang J, et al. Clinical Characteristics of 138 Hospitalized Patients With 2019 Novel Coronavirus-Infected Pneumonia in Wuhan, China. JAMA 2020.

[11] Ding Q, Lu P, Fan Y, Xia Y, Liu M. The clinical characteristics of pneumonia patients coinfected with 2019 novel coronavirus and influenza virus in Wuhan, China. J Med Virol 2020.

[12] Chen N, Zhou M, Dong X, Qu J, Gong F, Han Y, et al. Epidemiological and clinical characteristics of 99 cases of 2019 novel coronavirus pneumonia in Wuhan, China: a descriptive study. Lancet 2020;395(10223):507-13.

[13] Giacomelli A, Pezzati L, Conti F, Bernacchia D, Siano M, Oreni L, et al. Self-reported olfactory and taste disorders in SARS-CoV-2 patients: a cross-sectional study. Clin Infect Dis 2020 .

[14] Lechien JR, Chiesa-Estomba CM, De Siati DR, Horoi M, Le Bon SD, Rodriguez A, et al. Olfactory and gustatory dysfunctions as a clinical presentation of mild-to-moderate forms of the coronavirus disease (COVID-19): a multicenter European study. Eur Arch Otorhinolaryngol 2020.

[15] Yan CH, Faraji F, Prajapati DP, Boone CE, DeConde AS. Association of chemosensory dysfunction and Covid-19 in patients presenting with influenza-like symptoms. Int Forum Allergy Rhinol 2020. 
medRxiv preprint doi: https://doi.org/10.1101/2020.06.12.20128298; this version posted June 15, 2020. The copyright holder for this preprint (which was not certified by peer review) is the author/funder, who has granted medRxiv a license to display the preprint in perpetuity.

All rights reserved. No reuse allowed without permission.

Impact of COVID-19 on smell and taste

353 [16] Roland LT, Gurrola JG, 2nd, Loftus PA, Cheung SW, Chang JL. Smell and taste symptombased predictive model for COVID-19 diagnosis. Int Forum Allergy Rhinol 2020.

[17] Mao L, Jin H, Wang M, Hu Y, Chen S, He Q, et al. Neurologic Manifestations of Hospitalized Patients With Coronavirus Disease 2019 in Wuhan, China. JAMA Neurol 2020.

[18] Metlay JP, Waterer GW, Long AC, Anzueto A, Brozek J, Crothers K, et al. Diagnosis and Treatment of Adults with Community-acquired Pneumonia. An Official Clinical Practice Guideline of the American Thoracic Society and Infectious Diseases Society of America. Am J Respir Crit Care Med 2019;200(7):e45-e67.

[19] Fokkens WJ, Lund VJ, Hopkins C, Hellings PW, Kern R, Reitsma S, et al. European Position Paper on Rhinosinusitis and Nasal Polyps 2020. Rhinology 2020;58(Suppl S29):1-464.

[20] Zeng M, Wang H, Liao B, Wang H, Long XB, Ma J, et al. Comparison of efficacy of fluticasone propionate versus clarithromycin for postoperative treatment of different phenotypic chronic rhinosinusitis: a randomized controlled trial. Rhinology

[21] Malaty J, Malaty IA. Smell and taste disorders in primary care. Am Fam Physician 2013;88(12):852-9.

371 [22] Pellegrino R, Walliczek-Dworschak U, Winter G, Hull D, Hummel T. Investigation of chemosensitivity during and after an acute cold. Int Forum Allergy Rhinol 2017;7(2):18591. 
medRxiv preprint doi: https://doi.org/10.1101/2020.06.12.20128298; this version posted June 15, 2020. The copyright holder for this preprint (which was not certified by peer review) is the author/funder, who has granted medRxiv a license to display the preprint in perpetuity.

All rights reserved. No reuse allowed without permission.

Impact of COVID-19 on smell and taste

374 [23] Guan WJ, Liang WH, Zhao Y, Liang HR, Chen ZS, Li YM, et al. Comorbidity and its

375

376

377

378

379

380

381

382

383

384

385

386

387

388

389

390

391

392

393

394

395 impact on 1590 patients with Covid-19 in China: A Nationwide Analysis. Eur Respir J 2020.

[24] Cheng L, Chen J, Fu Q, He S, Li H, Liu Z, et al. Chinese Society of Allergy Guidelines for Diagnosis and Treatment of Allergic Rhinitis. Allergy Asthma Immunol Res 2018;10(4):300-53.

[25] Shi JB, Fu QL, Zhang H, Cheng L, Wang YJ, Zhu DD, et al. Epidemiology of chronic rhinosinusitis: results from a cross-sectional survey in seven Chinese cities. Allergy 2015;70(5):533-9.

[26] Qin C, Zhou L, Hu Z, Zhang S, Yang S, Tao Y, et al. Dysregulation of immune response in patients with COVID-19 in Wuhan, China. Clin Infect Dis 2020.

[27] Liu F, Xu A, Zhang Y, Xuan W, Yan T, Pan K, et al. Patients of COVID-19 may benefit from sustained lopinavir-combined regimen and the increase of eosinophil may predict the outcome of COVID-19 progression. Int J Infect Dis 2020.

[28] Wang JH, Kwon HJ, Jang YJ. Detection of parainfluenza virus 3 in turbinate epithelial cells of postviral olfactory dysfunction patients. Laryngoscope 2007;117(8):1445-9.

[29] Malhotra P, Luka A, McWilliams CS, Poeth KG, Schwartz R, Elfekey M, et al. Clinical Features of Respiratory Viral Infections Among Inpatients at a Major US Tertiary Care Hospital. South Med J 2016;109(8):481-6.

[30] Jaume F, Quinto L, Alobid I, Mullol J. Overuse of diagnostic tools and medications in acute rhinosinusitis in Spain: a population-based study (the PROSINUS study). BMJ Open 2018;8(1):e018788. 
medRxiv preprint doi: https://doi.org/10.1101/2020.06.12.20128298; this version posted June 15, 2020. The copyright holder for this preprint (which was not certified by peer review) is the author/funder, who has granted medRxiv a license to display the preprint in perpetuity.

All rights reserved. No reuse allowed without permission.

Impact of COVID-19 on smell and taste

[31] Suzuki M, Saito K, Min WP, Vladau C, Toida K, Itoh H, et al. Identification of viruses in patients with postviral olfactory dysfunction. Laryngoscope 2007;117(2):272-7.

[32] Yang W, Cao Q, Qin L, Wang X, Cheng Z, Pan A, et al. Clinical characteristics and imaging manifestations of the 2019 novel coronavirus disease (COVID-19):A multi-center study in Wenzhou city, Zhejiang, China. J Infect 2020;80(4):388-93.

[33] Luers JC, Rokohl AC, Loreck N, Wawer Matos PA, Augustin M, Dewald F, et al. Olfactory and Gustatory Dysfunction in Coronavirus Disease 19 (COVID-19). Clin Infect Dis 2020.

[34] Hwang CS. Olfactory neuropathy in severe acute respiratory syndrome: report of A case. Acta Neurol Taiwan 2006;15(1):26-8.

[35] Hummel T, Landis BN, Huttenbrink KB. Smell and taste disorders. GMS Curr Top Otorhinolaryngol Head Neck Surg 2011;10:Doc04.

[36] van Riel D, Verdijk R, Kuiken T. The olfactory nerve: a shortcut for influenza and other viral diseases into the central nervous system. J Pathol 2015;235(2):277-87.

[37] Mullol J, Marino-Sanchez F, Valls M, Alobid I, Marin C. The sense of smell in chronic rhinosinusitis. J Allergy Clin Immunol 2020;145(3):773-6.

[38] Baig AM, Khaleeq A, Ali U, Syeda H. Evidence of the COVID-19 Virus Targeting the CNS: Tissue Distribution, Host-Virus Interaction, and Proposed Neurotropic Mechanisms. ACS Chem Neurosci 2020;11(7):995-8.

[39] Netland J, Meyerholz DK, Moore S, Cassell M, Perlman S. Severe acute respiratory syndrome coronavirus infection causes neuronal death in the absence of encephalitis in mice transgenic for human ACE2. J Virol 2008;82(15):7264-75.

[40] Xu H, Zhong L, Deng J, Peng J, Dan H, Zeng X, et al. High expression of ACE2 receptor of 2019-nCoV on the epithelial cells of oral mucosa. Int J Oral Sci 2020;12(1):8. 
medRxiv preprint doi: https://doi.org/10.1101/2020.06.12.20128298; this version posted June 15, 2020. The copyright holder for this preprint (which was not certified by peer review) is the author/funder, who has granted medRxiv a license to display the preprint in perpetuity. All rights reserved. No reuse allowed without permission.

Impact of COVID-19 on smell and taste

419 [41] Wu C, Zheng S, Chen Y, Zheng M. Single-cell RNA expression profiling of ACE2, the putative receptor of Wuhan 2019-nCoV, in the nasal tissue. medRxiv 2020 DOI:

421 $101101 / 20200211200222282020$.

422 [42] Kumarhia D, He L, McCluskey LP. Inflammatory stimuli acutely modulate peripheral taste function. J Neurophysiol 2016;115(6):2964-75.

424

[43] Henkin RI, Schmidt L, Velicu I. Interleukin 6 in hyposmia. JAMA Otolaryngol Head Neck

425 Surg 2013;139(7):728-34.

426

[44] Soler ZM, Patel ZM, Turner JH, Holbrook EH. A primer on viral-associated olfactory loss in the era of COVID-19. Int Forum Allergy Rhinol 2020.

428

[45] Bousquet J, Akdis C, Jutel M, Bachert C, Klimek L, Agache I, et al. Intranasal corticosteroids in allergic rhinitis in COVID-19 infected patients: An ARIA-EAACI statement. Allergy 2020. 
medRxiv preprint doi: https://doi.org/10.1101/2020.06.12.20128298; this version posted June 15, 2020. The copyright holder for this preprint (which was not certified by peer review) is the author/funder, who has granted medRxiv a license to display the preprint in perpetuity.

All rights reserved. No reuse allowed without permission.

Impact of COVID-19 on smell and taste

\section{Table 1. Demographic and clinical characteristics of 1,172 etiologically confirmed patients}

\begin{tabular}{|c|c|c|c|c|}
\hline Characteristics & Total patients & Non-severe & Severe & $P$ value \\
\hline Subject, N (\%) & $1172(100)$ & $973(83.0)$ & $199(17.0)$ & - \\
\hline Gender, male, N (\%) & $577(49.2)$ & $480(49.3)$ & $97(48.7)$ & 0.94 \\
\hline Age, years, median (IQR) & $61(48,68)$ & $60(46,68)$ & $64(53,70)$ & $<0.01$ \\
\hline $\begin{array}{l}\text { Systemic signs and symptoms } \\
\mathrm{N}(\%)\end{array}$ & - & - & - & - \\
\hline Fever & $921(78.6)$ & 758 (77.9) & $163(81.9)$ & 0.21 \\
\hline Cough & $767(65.4)$ & $625(63.2)$ & $142(71.4)$ & 0.06 \\
\hline Myalgia & $172(14.7)$ & $136(14.0)$ & $36(18.1)$ & 0.13 \\
\hline Fatigue & $285(24.3)$ & $226(23.2)$ & $59(29.7)$ & 0.05 \\
\hline Anorexia & $274(23.4)$ & $214(22.0)$ & $60(30.2)$ & 0.01 \\
\hline Confusion & $6(0.5)$ & $3(0.3)$ & $3(1.5)$ & $\mathbf{0 . 0 3}$ \\
\hline Dizziness & $52(4.4)$ & $41(4.2)$ & $11(5.5)$ & 0.41 \\
\hline Any airway comorbidity, N (\%) & $203(17.3)$ & $179(18.4)$ & $24(12.1)$ & 0.03 \\
\hline $\mathrm{AR}$ & $115(9.8)$ & $99(10.2)$ & $16(8.0)$ & 0.43 \\
\hline CRS & $72(6.1)$ & $64(6.6)$ & $8(4.5)$ & 0.34 \\
\hline Asthma & $29(2.5)$ & $25(2.6)$ & $4(2.0)$ & 0.81 \\
\hline COPD & $10(0.9)$ & $10(1.0)$ & $0(0)$ & 0.23 \\
\hline Any nasal symptom, N (\%) & $342(29.2)$ & $275(28.3)$ & $67(33.7)$ & 0.15 \\
\hline Nasal obstruction, N (\%) & $101(8.6)$ & $82(8.4)$ & $19(9.5)$ & 0.58 \\
\hline Score, median (IQR) & $3(2,4)$ & $3(2,4)$ & $3(2,5)$ & 0.88 \\
\hline As first symptom, N (\%) & $2(0.2)$ & $1(0.1)$ & $1(0.5)$ & 0.31 \\
\hline Rhinorrhea, N (\%) & $120(10.3)$ & $100(10.3)$ & $20(10.1)$ & 0.99 \\
\hline Score, median (IQR) & $3(2,4)$ & $3(2,4)$ & $2.5(1.25,3.75)$ & 0.37 \\
\hline As first symptom, N (\%) & $9(0.8)$ & $8(0.8)$ & $1(0.5)$ & 0.99 \\
\hline Nasal itching, N (\%) & $57(4.9)$ & $45(4.6)$ & $12(6.0)$ & 0.37 \\
\hline Score, median (IQR) & $2(1.5,3)$ & $2(2,3.5)$ & $2(1,2)$ & 0.08 \\
\hline As first symptom, N (\%) & $1(0.1)$ & $1(0.1)$ & $0(0)$ & 0.99 \\
\hline Sneezing & $129(11.0)$ & $104(10.7)$ & $25(12.6)$ & 0.46 \\
\hline Score, median (IQR) & $2(1,3)$ & $2(1,3)$ & $2(1,2.5)$ & 0.77 \\
\hline As first symptom, N (\%) & $1(0.1)$ & $1(0.1)$ & $0(0)$ & 0.99 \\
\hline Loss of smell & $134(11.4)$ & $110(11.3)$ & $24(12.1)$ & 0.71 \\
\hline Score, median (IQR) & $5(4,9)$ & $5(4,8)$ & $7.5(3.25,10)$ & 0.37 \\
\hline As first symptom, $\mathrm{N}(\%)$ & $3(0.3)$ & $3(0.3)$ & $0(0)$ & 0.99 \\
\hline $\begin{array}{l}\text { Loss of smell recovered } \\
, \mathrm{N}(\%)\end{array}$ & $110(82.1 \%)$ & $90(81.8 \%)$ & $20(83.3 \%)$ & 0.99 \\
\hline $\begin{array}{l}\text { Recovery time, days, median } \\
\text { (IQR) }\end{array}$ & $8(6,13.25)$ & $8(5,12.25)$ & $8(6.25,14)$ & 0.67 \\
\hline Loss of taste & $242(20.6)$ & $199(20.5)$ & $43(21.6)$ & 0.70 \\
\hline Score, median (IQR) & $6(4,8)$ & $6(4,8)$ & $7(5,9)$ & 0.03 \\
\hline As first symptom, N (\%) & $5(0.4)$ & $4(0.4)$ & $1(0.5)$ & 0.99 \\
\hline Loss of taste recovered, $\mathrm{N}(\%)$ & $231(95.5 \%)$ & $190(95.5 \%)$ & $41(95.3 \%)$ & 0.99 \\
\hline $\begin{array}{l}\text { Recovery time, days, median } \\
\text { (IQR) }\end{array}$ & $7(5,14)$ & $7(5,14)$ & $7(5,14.5)$ & 0.76 \\
\hline
\end{tabular}

Abbreviations: IQR, interquartile range; AR, allergic rhinitis, CRS, chronic rhinosinusitis; COPD, chronic

442 obstructive pulmonary disease. Data are presented as medians and interquartile ranges (IQR) for continuous

443 variables and numbers with percentage for categorical variables. $P$ values were calculated from Kruskal-

$444 \quad$ Wallis, $\chi 2$ test or Fisher's exact test. 
medRxiv preprint doi: https://doi.org/10.1101/2020.06.12.20128298; this version posted June 15, 2020. The copyright holder for this preprint (which was not certified by peer review) is the author/funder, who has granted medRxiv a license to display the preprint in perpetuity. All rights reserved. No reuse allowed without permission.

Impact of COVID-19 on smell and taste

Table 2. The comparison of 242 patients with different severity of loss of taste

\begin{tabular}{|c|c|c|c|c|}
\hline Characteristics & Mild (0-3) & Moderate (4-7) & Severe $(8-10)$ & $P$ value \\
\hline Subject, N (\%) & $46(19.0)$ & $118(48.8)$ & $78(32.2)$ & - \\
\hline Gender, male, $\mathrm{N}(\%)$ & $21(45.7)$ & $59(50.0)$ & $39(50.0)$ & 0.16 \\
\hline Age, years, median (IQR) & $55(42,67)$ & $58.5(43.75,67)$ & $58.5(48.5,66)$ & 0.88 \\
\hline Severe cases, N (\%) & $7(15.2)$ & $15(12.7)$ & $21(26.9)^{\#}$ & 0.03 \\
\hline Loss of taste recovered, $\mathrm{N}(\%)$ & $45(97.8)$ & $110(93.2)$ & $76(97.4)$ & 0.26 \\
\hline Recovery time, days, median (IQR) & $5(3.5,8)$ & $8(6,13.25)^{* *}$ & $10(5,15)^{* *}$ & $<\mathbf{0 . 0 1}$ \\
\hline Any airway comorbidity, N (\%) & $6(13.0)$ & $26(22.0)$ & $13(16.7)$ & 0.36 \\
\hline AR & $2(4.3)$ & $12(10.2)$ & $9(11.5)$ & 0.39 \\
\hline CRS & $3(6.5)$ & $10(5.6)$ & $4(5.1)$ & 0.66 \\
\hline Asthma & $1(2.2)$ & $3(2.5)$ & $2(2.6)$ & 0.99 \\
\hline COPD & $0(0)$ & $3(2.5)$ & $0(0)$ & 0.20 \\
\hline $\begin{array}{l}\text { Systemic signs and symptoms, } \\
\mathrm{N}(\%)\end{array}$ & - & - & - & - \\
\hline Fever & $37(80.4)$ & $101(85.6)$ & $66(84.6)$ & 0.71 \\
\hline Cough & $29(61.7)$ & $78(66.1)$ & $53(70.0)$ & 0.77 \\
\hline Myalgia & $7(15.2)$ & $18(15.3)$ & $10(12.8)$ & 0.88 \\
\hline Fatigue & $12(26.1)$ & $34(28.8)$ & $18(23.1)$ & 0.80 \\
\hline Anorexia & $12(26.1)$ & $30(25.4)$ & $18(23.1)$ & 0.91 \\
\hline Confusion & $1(2.2)$ & $0(0)$ & $0(0)$ & 0.12 \\
\hline Dizziness & $2(4.3)$ & $3(2.5)$ & $4(5.1)$ & 0.63 \\
\hline Laboratory results, median (IQR) & - & - & - & - \\
\hline Blood routine, subject, $\mathrm{N}$ & 46 & 118 & 78 & - \\
\hline White blood cell count, $\times 10^{9} / \mathrm{L}$ & $5.7(3.8,6.8)$ & $5.7(4.5,7.5)$ & $5.8(4.6,7.4)$ & 0.48 \\
\hline Neutrophil count, $\times 10^{9} / \mathrm{L}$ & $3.5(2.6,5.6)$ & $3.8(2.7,5.5)$ & $4.0(2.8,5.5)$ & 0.96 \\
\hline Neutrophil percentage & $66.8(57.0,75.0)$ & $64.1(57.3,72.6)$ & $66.8(58.7,73.0)$ & 0.88 \\
\hline Lymphocyte count, $\times 10^{9} / \mathrm{L}$ & $1.1(0.8,2.0)$ & $1.3(0.9,1.7)$ & $1.2(0.9,1.6)$ & 0.80 \\
\hline Lymphocyte percentage & $23.1(18,31.8)$ & $22.8(16,30.4)$ & $21.7(15.4,28.7)$ & 0.53 \\
\hline Monocyte count, $\times 10^{9} / \mathrm{L}$ & $0.5(0.4,0.6)$ & $0.5(0.4,0.6)$ & $0.5(0.4,0.7)$ & 0.33 \\
\hline Monocyte percentage & $8.5(6.1,11.4)$ & $9.0(7.0,11.1)$ & $9.5(7.8,10.6)$ & 0.33 \\
\hline Eosinophil count, $\times 10^{9 /} \mathrm{L}$ & $0.03(0,0.08)$ & $0.06(0.01,0.11)$ & $0.04(0,0.09)$ & 0.14 \\
\hline Eosinophil percentage & $0.4(0,1.2)$ & $0.95(0.2,1.8)$ & $0.6(0,1.7)$ & 0.07 \\
\hline Platelet count, $\times 10^{9} / \mathrm{L}$ & $227(187.8,312)$ & $252(195,314)$ & $260(190.8,328)$ & 0.27 \\
\hline Hemoglobin, $\mathrm{g} / \mathrm{L}$ & $128(114.8,137.5)$ & $129(113.8,137)$ & $129(120,141.3)$ & 0.36 \\
\hline $\begin{array}{l}\text { Liver and renal function test, } \\
\text { subject, } \mathrm{N}\end{array}$ & 46 & 118 & 78 & - \\
\hline Alanine aminotransferase, $\mathrm{U} / \mathrm{L}$ & $22.5(13,35.3)$ & $24.5(16.8,44)$ & $29(17,43)$ & 0.15 \\
\hline Aspartate aminotransferase, U/L & $24.5(19,35)$ & $21(18,34)$ & $26.5(19,37.5)$ & 0.30 \\
\hline Albumin, $\mathrm{g} / \mathrm{L}$ & $37.2(33.1,41.8)$ & $36.7(32.7,40.2)$ & $35.1(32.3,37.6)$ & 0.08 \\
\hline Globulin, $\mathrm{g} / \mathrm{L}$ & $32.2(29.3,34.9)$ & $32.4(22.2,35.8)$ & $33.2(29.8,36.5)$ & 0.48 \\
\hline Alkaline phosphatase, U/L & $58(50,72.75)$ & $63(55,80.25)$ & $60(52.25,81.5)$ & 0.15 \\
\hline Total bilirubin, $\mu \mathrm{mol} / \mathrm{L}$ & $8.4(5.6,13)$ & $8.4(6.4,11.7)$ & $8.8(7,11.4)$ & 0.83 \\
\hline Lactose dehydrogenase, $\mathrm{U} / \mathrm{L}$ & $\begin{array}{c}229.5(179.5 \\
305.8)\end{array}$ & $239.5(197,300)$ & $276.5(224.5,347.5)^{* \#}$ & 0.04 \\
\hline Urea, $\mathrm{mmol} / \mathrm{L}$ & $4.3(3.2,5.7)$ & $4.1(3.3,5.2)$ & $3.75(3.2,4.83)$ & 0.88 \\
\hline Creatinine, $\mu \mathrm{mol} / \mathrm{L}$ & $67.5(59,77)$ & $69(55,82)$ & $65.5(56,81)$ & 0.98 \\
\hline Urine acid, $\mu \mathrm{mol} / \mathrm{L}$ & $\begin{array}{c}276.9(222.8 \\
338.2)\end{array}$ & $248(190.7,327.5)$ & $241.4(201.3,293.8)$ & 0.13 \\
\hline $\begin{array}{l}\text { Glomerular filtration, } \\
\mathrm{ml} / \mathrm{min} / 1.73 \mathrm{~m} 2\end{array}$ & $93.3(82.9,109.5)$ & $95.7(83.9,107.9)$ & $94.2(83.75,106.1)$ & 0.91 \\
\hline Electrolytes, subject, $\mathrm{N}$ & 46 & 118 & 78 & - \\
\hline $\mathrm{K}+, \mathrm{mmol} / \mathrm{L}$ & $4.2(3.9,4.6)$ & $4.2(3.9,4.5)$ & $4.1(3.8,4.4)$ & 0.15 \\
\hline
\end{tabular}


medRxiv preprint doi: https://doi.org/10.1101/2020.06.12.20128298; this version posted June 15, 2020. The copyright holder for this preprint (which was not certified by peer review) is the author/funder, who has granted medRxiv a license to display the preprint in perpetuity.

All rights reserved. No reuse allowed without permission.

Impact of COVID-19 on smell and taste

\begin{tabular}{|c|c|c|c|c|}
\hline $\mathrm{Na}+, \mathrm{mmol} / \mathrm{L}$ & $\begin{array}{c}139.4(137.8 \\
141.6)\end{array}$ & $140.5(138.2,142)$ & $139.5(137.7,141.3)$ & 0.31 \\
\hline $\mathrm{Cl}-, \mathrm{mmol} / \mathrm{L}$ & $100.8(99,103)$ & $\begin{array}{l}101.6(99.1 \\
103.7)\end{array}$ & $100.8(98.1,103.1)$ & 0.34 \\
\hline $\mathrm{Ca}+, \mathrm{mmol} / \mathrm{L}$ & $2.14(2.04,2.24)$ & $2.16(2.08,2.25)$ & $2.15(2.09,2.22)$ & 0.64 \\
\hline $\mathrm{ESR}, \mathrm{mm} / \mathrm{H}$ & $25(16.75,58)$ & $32(13,60)$ & $39(18,64.75)$ & 0.53 \\
\hline CRP, mg/L & $4.65(1.43,29.6)$ & $4.4(1.2,34)$ & $7.5(1.85,42.85)$ & 0.33 \\
\hline Cardiac troponin I, pg/mL & $2.5(1.9,6.9)$ & $2.9(1.9,7)$ & $3.5(1.9,6.9)$ & 0.81 \\
\hline $\begin{array}{l}\text { Inflammatory mediators, subject, } \\
\mathrm{N}\end{array}$ & 35 & 99 & 72 & - \\
\hline Ferritin, ug/L & $467.7(183,633.5)$ & $531.1(294,827.8)$ & $576.7(310.8,1268)$ & 0.21 \\
\hline Interleukin-10, pg/mL & $5(5,5)$ & $5(5,5)$ & $5(5,5)$ & 0.25 \\
\hline Interleukin-1 $\beta, \mathrm{pg} / \mathrm{mL}$ & $5(5,5)$ & $5(5,5)$ & $5(5,5)$ & 0.55 \\
\hline Interleukin-2 receptor, $\mathrm{U} / \mathrm{mL}$ & $465(242,624)$ & $498(376,706)$ & $571(362.8,792.5)$ & 0.13 \\
\hline Interleukin-6, pg/mL & $3.7(1.7,14.9)$ & $3.8(1.9,10.5)$ & $8.1(2.3,23.8)^{* \#}$ & 0.03 \\
\hline Interleukin-8, pg/mL & $6.5(5,10.5)$ & $10.4(5.5,19.5)^{*}$ & $9.9(5.3,18.7)^{*}$ & 0.04 \\
\hline Tumor necrosis factor, $\mathrm{pg} / \mathrm{mL}$ & $7(5.2,9.7)$ & $7(5.1,9.1)$ & $7.9(5.1,10.9)$ & 0.32 \\
\hline Procalcitonin, ng/mL & $0.05(0.03,0.07)$ & $0.05(0.03,0.08)$ & $0.05(0.02,0.09)$ & 0.98 \\
\hline $\begin{array}{l}\text { Immunoglobulins and } \\
\text { complements, subject, } \mathrm{N}\end{array}$ & 11 & 43 & 25 & - \\
\hline $\operatorname{IgA}, \mathrm{g} / \mathrm{L}$ & $2.2(1.6,3.1)$ & $2.2(1.8,2.6)$ & $2.2(1.6,2.5)$ & 0.97 \\
\hline $\operatorname{IgG}, \mathrm{g} / \mathrm{L}$ & $10.6(9.2,11.6)$ & $11.1(9.6,13.2)$ & $11.6(10,13.6)$ & 0.51 \\
\hline IgM, g/L & $0.79(0.64,0.96)$ & $1(0.79,1.3)$ & $0.91(0.65,1.4)$ & 0.12 \\
\hline $\mathrm{C} 3, \mathrm{~g} / \mathrm{L}$ & $1(0.83,1.13)$ & $0.86(0.78,1)$ & $0.9(0.74,1.07)$ & 0.34 \\
\hline $\mathrm{C} 4, \mathrm{~g} / \mathrm{L}$ & $0.24(0.22,0.36)$ & $0.22(0.18,0.28)$ & $0.26(0.2,0.3)$ & 0.16 \\
\hline
\end{tabular}

Abbreviations, IQR, interquartile range; AR, allergic rhinitis, CRS, chronic rhinosinusitis; COPD, chronic

448 obstructive pulmonary disease; ERS, erythrocyte sedimentation rate; CRP, C-reactive protein; Ig,

449 immunoglobulin; C, complement. Data is presented as medians and interquartile ranges (IQR) for

450 continuous variables and numbers with percentage for categorical variables. $P$ values were calculated from

451 Kruskal-Wallis, $\chi 2$ test or Fisher's exact test. “*”, vs mild, $P<0.05$, “**”, vs mild, $P<0.01$, “\#”, vs

452 moderate, $P<0.05$.

453

454

455

456

457 
medRxiv preprint doi: https://doi.org/10.1101/2020.06.12.20128298; this version posted June 15, 2020. The copyright holder for this preprint (which was not certified by peer review) is the author/funder, who has granted medRxiv a license to display the preprint in perpetuity. All rights reserved. No reuse allowed without permission.

Impact of COVID-19 on smell and taste

Table 3. The comparison of 134 patients with different severity of loss of smell

\begin{tabular}{|c|c|c|c|c|}
\hline Characteristic & Mild (0-3) & Moderate (4-7) & Severe (8-10) & $P$ value \\
\hline Subject, N (\%) & $32(23.9)$ & $48(35.8)$ & $54(40.3)$ & - \\
\hline Gender, male, N (\%) & $10(31.3)$ & $17(35.4)$ & $27(50.0)$ & 0.16 \\
\hline Age, years, median (IQR) & $58(49.25,63.75)$ & $57(46,68)$ & $57.5(42.25,65.25)$ & 0.82 \\
\hline Severe cases, $\mathrm{N}$ & $6(18.8)$ & $6(12.5)$ & $12(22.2)$ & 0.44 \\
\hline Loss of smell recovered, N (\%) & $28(87.5)$ & $36(75.0)$ & $46(85.2)$ & 0.37 \\
\hline $\begin{array}{l}\text { Recovery time, days, } \\
\text { Median (IQR) }\end{array}$ & $7(5,14)$ & $7(5.25,10)$ & $10(7,17.5)$ & 0.08 \\
\hline Any airway comorbidity & $8(25.0)$ & $10(20.8)$ & $9(16.7)$ & 0.64 \\
\hline $\mathrm{AR}$ & $2(6.3)$ & $5(10.4)$ & $7(13.0)$ & 0.61 \\
\hline CRS & $3(9.4)$ & $3(6.3)$ & $3(5.6)$ & 0.78 \\
\hline Asthma & $3(9.4)$ & $1(2.1)$ & $0(0)^{*}$ & 0.04 \\
\hline COPD & $0(0)$ & $1(2.1)$ & $0(0)$ & 0.45 \\
\hline Systemic signs and symptoms & - & - & - & - \\
\hline Fever & $22(68.8)$ & $35(72.9)$ & $44(81.5)$ & 0.37 \\
\hline Cough & $23(71.9)$ & $32(66.7)$ & $88(65.7)$ & 0.58 \\
\hline Myalgia & $9(28.1)$ & $8(16.7)$ & $7(13.0)$ & 0.20 \\
\hline Fatigue & $13(40.6)$ & $12(25.0)$ & $11(20.4)$ & 0.11 \\
\hline Anorexia & $4(12.5)$ & $11(22.9)$ & $15(27.8)$ & 0.26 \\
\hline Confusion & $0(0)$ & $0(0)$ & $0(0)$ & - \\
\hline Dizziness & $2(6.3)$ & $3(6.3)$ & $4(7.4)$ & 0.97 \\
\hline Laboratory results & - & - & - & - \\
\hline Blood routine, subject, $\mathrm{N}$ & 32 & 48 & 54 & - \\
\hline White blood cell count, $\times 10^{9} / \mathrm{L}$ & $5.1(3.7,6.5)$ & $5.7(4.6,7.5)$ & $5.8(4.5,7.8)$ & 0.08 \\
\hline Neutrophil count, $\times 10^{9} / \mathrm{L}$ & $2.9(2.1,5.0)$ & $3.7(2.7,5.2)$ & $4.2(2.8,5.4)$ & 0.09 \\
\hline Neutrophil percentage & $61.2(53.0,73.1)$ & $64.1(57.1,74.8)$ & $70.2(58.6,74.7)$ & 0.33 \\
\hline Lymphocyte count, $\times 10^{9} / \mathrm{L}$ & $1.3(0.8,1.6)$ & $1.3(1.0,1.7)$ & $1.3(0.9,1.6)$ & 0.77 \\
\hline Lymphocyte percentage & $26.2(17.3,34.2)$ & $24.9(16.2,31.2)$ & $22.2(16.2,27.0)$ & 0.46 \\
\hline Monocyte count, $\times 10^{9} / \mathrm{L}$ & $0.4(0.4,0.5)$ & $0.5(0.4,0.6)$ & $0.5(0.4,0.7)$ & 0.09 \\
\hline Monocyte percentage & $9.0(7.2,10.9)$ & $8.9(7.0,10.1)$ & $8.5(6.5,10.5)$ & 0.67 \\
\hline Eosinophil count, $\times 10^{9 /} \mathrm{L}$ & $0.03(0,0.1)$ & $0.05(0.02,0.08)$ & $0.04(0.01,0.09)$ & 0.61 \\
\hline Eosinophil percentage & $0.85(0,1.8)$ & $0.75(0.3,1.7)$ & $0.75(0.3,1.7)$ & 0.89 \\
\hline Platelet count, $\times 10^{9} / \mathrm{L}$ & $232.5(143.8,264.5)$ & $259.5(199.5,308)$ & $238(188.5,316)$ & 0.14 \\
\hline Hemoglobin, g/L & $125.5(113,135.3)$ & $125.5(114,134.8)$ & $128.5(119.5,143.3)$ & 0.12 \\
\hline $\begin{array}{l}\text { Liver and renal function test, } \\
\text { subject, } N\end{array}$ & 32 & 48 & 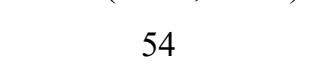 & - \\
\hline Alanine aminotransferase, U/L & $18(13,49)$ & $20(12,31)^{*}$ & $29(17,43)$ & 0.04 \\
\hline Aspartate aminotransferase, & $21.5(18.3,31.8)$ & $20.5(16,29)$ & $25(16,33.3)$ & 0.48 \\
\hline \multicolumn{5}{|l|}{$\mathrm{U} / \mathrm{L}$} \\
\hline Albumin, g/L & $37.1(32.1,39.9)$ & $36.6(31.5,41)$ & $34.5(32.4,38.7)$ & 0.81 \\
\hline Globulin, $\mathrm{g} / \mathrm{L}$ & $31.8(29.4,34.4)$ & $32.4(26.2,38.9)$ & $33.1(28.9,36)$ & 0.89 \\
\hline Alkaline phosphatase, U/L & $67.5(55,81.3)$ & $59(52,74.3)$ & $58.5(50,79.3)$ & 0.26 \\
\hline Total bilirubin, $\mu \mathrm{mol} / \mathrm{L}$ & $8.4(6.7,10.1)$ & $9.7(7.3,11.6)$ & $8.6(6.3,11.6)$ & 0.68 \\
\hline Lactose dehydrogenase, U/L & $236(194,298.8)$ & $231.5(189.3,267.5)$ & $264.5(188.8,367.3)$ & 0.27 \\
\hline Urea, $\mathrm{mmol} / \mathrm{L}$ & $3.8(3.4,4.4)$ & $4.5(3.3,5.2)$ & $4.0(3.3,5.5)$ & 0.47 \\
\hline Creatinine, $\mu \mathrm{mol} / \mathrm{L}$ & $51(37,59)$ & $62(53,78.3)$ & $64.5(55,80)$ & 0.43 \\
\hline Urine acid, $\mu \mathrm{mol} / \mathrm{L}$ & $242.9(182.1,302.5)$ & $271(223.5,327.1)$ & $233.5(198.5,282.3)$ & 0.11 \\
\hline $\begin{array}{l}\text { Glomerular filtration, } \\
\mathrm{ml} / \mathrm{min} / 1.73 \mathrm{~m} 2\end{array}$ & $97.1(90.4,109.4)$ & $93.4(78.9,107.6)$ & $95.7(88.1,110.1)$ & 0.54 \\
\hline Electrolytes, subject, $\mathrm{N}$ & 32 & 48 & 54 & - \\
\hline $\mathrm{K}+, \mathrm{mmol} / \mathrm{L}$ & $4.0(3.8,4.2)$ & $4.1(3.7,4.3)$ & $4.1(3.7,4.5)$ & 0.56 \\
\hline $\mathrm{Na}+, \mathrm{mmol} / \mathrm{L}$ & $140.9(137.6,142.3)$ & $139.8(138.1,141.8)$ & $139.4(137.7,140.9)$ & 0.17 \\
\hline $\mathrm{Cl}-, \mathrm{mmol} / \mathrm{L}$ & $101.2(99.3,104.3)$ & $101.9(100.3,103.7)$ & $101(98,103.2)$ & 0.41 \\
\hline
\end{tabular}


medRxiv preprint doi: https://doi.org/10.1101/2020.06.12.20128298; this version posted June 15, 2020. The copyright holder for this preprint (which was not certified by peer review) is the author/funder, who has granted medRxiv a license to display the preprint in perpetuity.

All rights reserved. No reuse allowed without permission.

Impact of COVID-19 on smell and taste

\begin{tabular}{|c|c|c|c|c|}
\hline $\mathrm{Ca}+, \mathrm{mmol} / \mathrm{L}$ & $2.15(2.04,2.26)$ & $2.20(2.08,2.27)$ & $2.15(2.08,2.23)$ & 0.46 \\
\hline Cardiac troponin I, pg/mL & $4.7(3,13.9)$ & $6.6(2.7,11.8)$ & $5(3.2,8.2)$ & 0.84 \\
\hline $\mathrm{ESR}, \mathrm{mm} / \mathrm{H}$ & $48(22,67)$ & $38.5(12,59.3)$ & $26.5(10.5,53)$ & 0.15 \\
\hline CRP, mg/L & $14.1(2,35.8)$ & $4(1.6,28.4)$ & $5.7(1.5,42.7)$ & 0.57 \\
\hline $\begin{array}{l}\text { Inflammatory mediators, subject } \\
, \mathrm{N}\end{array}$ & 26 & 45 & 48 & - \\
\hline Ferritin, ug/L & $515.9(205.5,1304)$ & $426.7(228.1,645.3)$ & $663.1(328.3,1050)$ & 0.23 \\
\hline Interleukin-10, pg/mL & $5(5,5.3)$ & $5(5,5)^{*}$ & $5(5,5.7)$ & 0.04 \\
\hline Interleukin- $1 \beta, \mathrm{pg} / \mathrm{mL}$ & $5(5,5)$ & $5(5,5)$ & $5(5,5)$ & $0.24-$ \\
\hline Interleukin-2 receptor, $\mathrm{U} / \mathrm{mL}$ & $523(344,751)$ & $428(279,688)$ & $554.5(322.3,711.3)$ & 0.47 \\
\hline Interleukin-6, pg/mL & $3.8(2.1,13.6)$ & $3.7(1.5,8.6)$ & $4.1(1.6,20.0)$ & 0.46 \\
\hline Interleukin-8, pg/mL & $7.7(5,16.2)$ & $9.1(5.2,12.3)$ & $10.2(5.1,21.8)$ & 0.42 \\
\hline Tumor necrosis factor, $\mathrm{pg} / \mathrm{mL}$ & $8.6(5.7,9.9)$ & $6(4.7,7.2)^{*}$ & $8.0(5.6,10.3)$ & $<0.01$ \\
\hline Procalcitonin, ng/mL & $0.05(0.04,0.09)$ & $0.04(0.02,0.07)$ & $0.05(0.03,0.09)$ & 0.35 \\
\hline $\begin{array}{l}\text { Immunoglobulins and } \\
\text { complements, subject, } \mathrm{N}\end{array}$ & 8 & 17 & 21 & - \\
\hline $\operatorname{IgA}, g / L$ & $2.1(1.9,2.3)$ & $2.2(1.2,2.8)$ & $2.3(1.6,2.8)$ & 0.83 \\
\hline $\operatorname{IgG}, \mathrm{g} / \mathrm{L}$ & $10.5(9.5,15.9)$ & $12.9(10.8,15.5)$ & $12.5(10.6,14.5)$ & 0.55 \\
\hline IgM, g/L & $0.94(0.81,1.2)$ & $1(0.82,1.34)$ & $0.86(0.67,1.21)$ & 0.56 \\
\hline $\mathrm{C} 3, \mathrm{~g} / \mathrm{L}$ & $0.91(0.72,1.1)$ & $0.89(0.72,0.97)$ & $0.92(0.78,1.05)$ & 0.68 \\
\hline $\mathrm{C} 4, \mathrm{~g} / \mathrm{L}$ & $0.23(0.19,0.24)$ & $0.18(0.11,0.21)$ & $0.21(0.16,0.33)$ & 0.94 \\
\hline \multicolumn{5}{|c|}{$\begin{array}{l}\text { Abbreviations, IQR, interquartile range; AR, allergic rhinitis, CRS, chronic rhinosinusitis; COPD, chronic } \\
\text { obstructive pulmonary disease; ERS, erythrocyte sedimentation rate; CRP, C-reactive protein; Ig, } \\
\text { immunoglobulin; C, complement. Data is presented as medians and interquartile ranges (IQR) for } \\
\text { continuous variables and numbers with percentage for categorical variables. } P \text { values were calculated from }\end{array}$} \\
\hline Kruskal-Wallis, $\chi 2$ test or Fisl & exact test. "*”, v & $\mathrm{d}, P<0.05$ & & \\
\hline
\end{tabular}

465

466

467

468

469

470

471

472 
medRxiv preprint doi: https://doi.org/10.1101/2020.06.12.20128298; this version posted June 15, 2020. The copyright holder for this preprint (which was not certified by peer review) is the author/funder, who has granted medRxiv a license to display the preprint in perpetuity.

All rights reserved. No reuse allowed without permission.

Impact of COVID-19 on smell and taste

\section{$474 \quad$ Figure Legends}

475

476

477

478

479

480

481

482

483

484

485

486

487

488

489

490

491

492

493

494

Figure 1. The impact of coronavirus disease 2019 (COVID-19) on smell and taste. (A) The

prevalence of self-reported loss of smell and taste in severe and non-severe COVID-19 patients.

The frequencies are indicated on the top of the columns. (B) The severity of self-reported loss of smell and taste in severe and non-severe COVID-19 patients. Severity of self-reported loss of smell and taste symptom was scored by patients on a numerical rating scale of $0-10$, with 0 being "no complaint whatsoever" and 10 being "the worst imaginable complaint. (C) The recovery time of self-reported smell and state dysfunction in severe and non-severe COVID-19 patients. (D) The pattern of recovery time for patients with self-reported loss of smell and taste. The frequencies are indicated on the tope of columns. ${ }^{*} P<0.05$ compared to non-severe COVID-19.

Figure 2. The recovery time of patients with different severity of loss of smell and loss of taste. Severity of self-reported loss of smell and taste symptom was scored by patients on a numerical rating scale of $0-10$, with 0 being "no complaint whatsoever" and 10 being "the worst imaginable complaint. $* * P<0.01$ compared to mild loss of taste.

Figure 3. Correlations between loss of taste scores and serum levels of IL-6 (A), IL-8 (B), lactose dehydrogenase (LDH) (C). Severity of self-reported loss of taste was scored by patients on a numerical rating scale of $0-10$, with 0 being "no complaint whatsoever" and 10 being "the worst imaginable complaint. 
medRxiv preprint doi: https://doi.org/10.1101/2020.06.12.20128298; this version posted June 15, 2020. The copyright holder for this preprint (which was not certified by peer review) is the author/funder, who has granted medRxiv a license to display the preprint in perpetuity. All rights reserved. No reuse allowed without permission.

Impact of COVID-19 on smell and taste

\section{$495 \quad$ Figure 1}

A

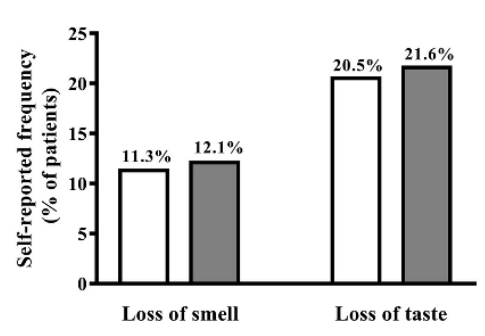

C

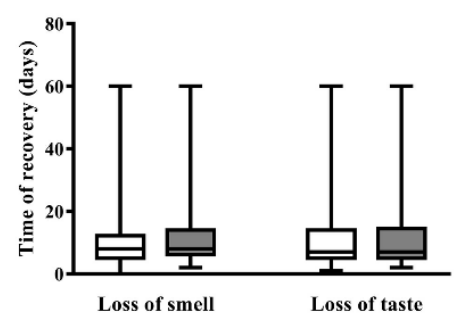

B

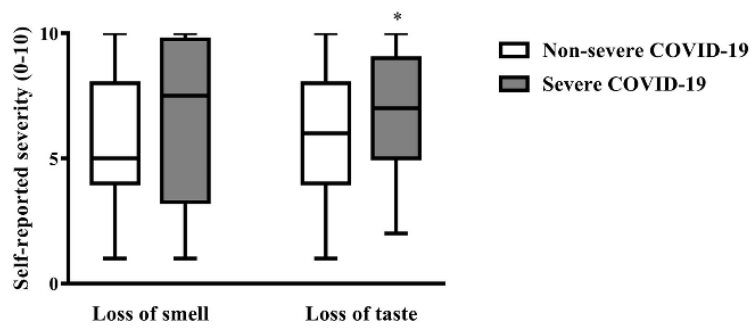

D

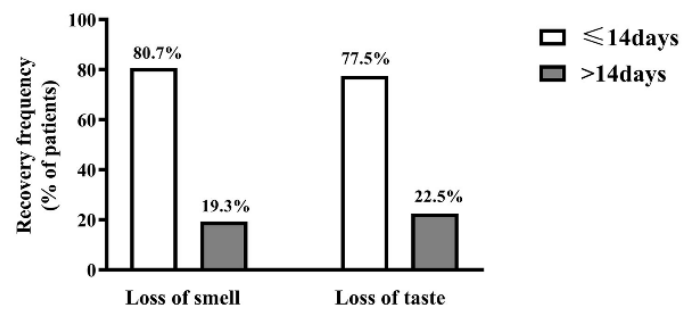

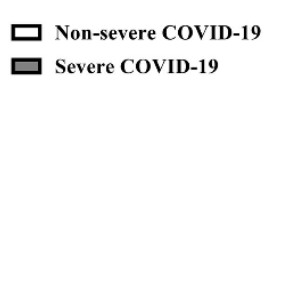


medRxiv preprint doi: https://doi.org/10.1101/2020.06.12.20128298; this version posted June 15, 2020. The copyright holder for this preprint (which was not certified by peer review) is the author/funder, who has granted medRxiv a license to display the preprint in perpetuity.

All rights reserved. No reuse allowed without permission.

Figure 2

Impact of COVID-19 on smell and taste

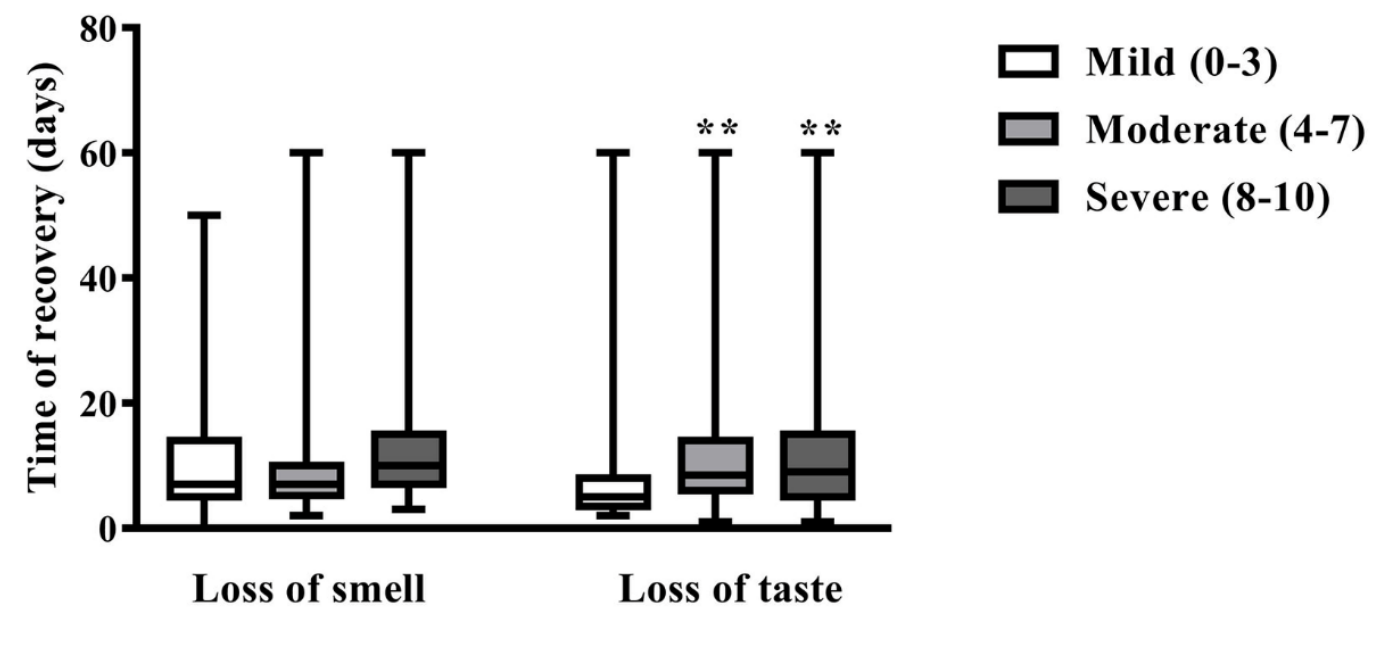


medRxiv preprint doi: https://doi.org/10.1101/2020.06.12.20128298; this version posted June 15, 2020. The copyright holder for this preprint (which was not certified by peer review) is the author/funder, who has granted medRxiv a license to display the preprint in perpetuity. All rights reserved. No reuse allowed without permission.

Impact of COVID-19 on smell and taste

501

Figure 3
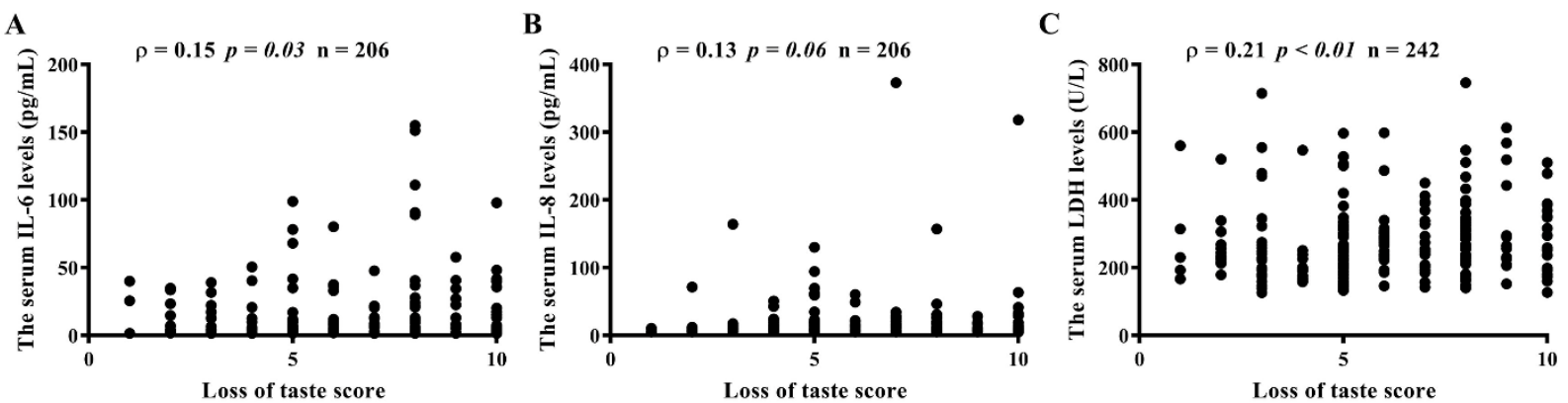

502 